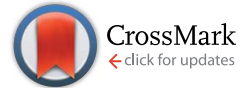

Cite this: Chem. Sci., 2015, 6, 5578

\title{
Terpyridine-Cu(॥) targeting human telomeric DNA to produce highly stereospecific G-quadruplex DNA metalloenzyme $\dagger$
}

\author{
Yinghao Li, ${ }^{\text {ab }}$ Mingpan Cheng, ${ }^{\text {ab }}$ Jingya Hao, ${ }^{\text {ab }}$ Changhao Wang, ${ }^{a}$ Guoqing Jia*a \\ and Can Li*a
}

\begin{abstract}
The cofactors commonly involved in natural enzymes have provided the inspiration for numerous advances in the creation of artificial metalloenzymes. Nevertheless, to design an appropriate cofactor for a given biomolecular scaffold or vice versa remains a challenge in developing efficient catalysts in biochemistry. Herein, we extend the idea of G-quadruplex-targeting anticancer drug design to construct a Gquadruplex DNA metalloenzyme. We found that a series of terpyridine-Cu(॥) complexes (CuLn) can serve as excellent cofactors to dock with human telemetric G-quadruplex DNA. The resulting Gquadruplex DNA metalloenzyme utilising CuL1 catalyzes an enantioselective Diels-Alder reaction with enantioselectivity of $>99 \%$ enantiomeric excess and about 73 -fold rate acceleration compared to CuL1 alone. The terpyridine-Cu(॥) complex cofactors demonstrate dual functions, both as an active site to perform catalysis and as a structural regulator to promote the folding of human telemetric G-quadruplex

DNA towards excellent catalysts.
\end{abstract}

Received 16th April 2015

Accepted 23rd June 2015

DOI: $10.1039 /$ c5sc01381j

www.rsc.org/chemicalscience

\section{Introduction}

Enzymes, the catalysts of biological systems, can mediate a wide range of chemical reactions with high catalytic rates and perfect regio-/stereoselectivity. ${ }^{\mathbf{1} 2}$ Cofactors usually play a crucial role in this process. ${ }^{1}$ Metal complexes are one important type of cofactor that occur in many natural proteins to mediate various reactions. ${ }^{3}$ In a biomimetic spirit, catalytic metal complexes have also been widely used as cofactors to combine covalently or non-covalently with biomacromolecules, such as proteins, apo-enzymes and antibodies, to construct artificial metalloenzymes. ${ }^{4-8}$ In particular, the chiral feature of biomacromolecules makes artificial metalloenzymes an ideal catalyst for enantioselective reactions. ${ }^{9-12}$

DNA has served as a new biological scaffold in constructing artificial metalloenzymes for enantioselective catalysis. ${ }^{\mathbf{1 2 - 1 4}}$ Roelfes, Boersma and Feringa found the cofactor $\mathrm{Cu}(\mathrm{II})-\left(4,4^{\prime}-\right.$ dimethyl-2,2'-dipyridyl) could be most compatible with doublestranded DNA (dsDNA). ${ }^{15}$ The resulting artificial dsDNA metalloenzyme proceeds with excellent enantioselectivity in a series of enantioselective reactions. ${ }^{\mathbf{1 6 - 2 6}}$ Recently, G-quadruplex DNA, due to its diverse and tunable chiral structures, ${ }^{27-31}$ has become

${ }^{a}$ State Key Laboratory of Catalysis, Dalian Institute of Chemical Physics, Chinese Academy of Sciences, Dalian 116023,China.E-mail: canli@dicp.ac.cn; gqjia@dicp. ac.cn

${ }^{b}$ University of Chinese Academy of Sciences, No. 19A Yuquan Road, Beijing, 100049, China

$\dagger$ Electronic supplementary information (ESI) available: Experimental details, ESI figures and tables, ${ }^{1} \mathrm{H}$ NMR spectra and HPLC traces. See DOI: $10.1039 / \mathrm{c} 5 \mathrm{sc} 01381 \mathrm{j}$ another candidate in constructing DNA metalloenzymes for enantioselective reactions. Considerable efforts have been made to develop cofactors for G-quadruplex DNA, including a $\mathrm{Cu}(\mathrm{II})$-bipyridine complex and its analogs by Moses et al., ${ }^{32}$ $\mathrm{Cu}$ (II) ions by our group, ${ }^{33-36}$ and $\mathrm{Cu}(\mathrm{II})$ cationic porphyrin by Hennecke et al. ${ }^{37}$ However, these G-quadruplex metalloenzymes only provide modest enantioselectivity for enantioselective reactions, which is most possibly due to the fact that these cofactors cannot fit well with the G-quadruplex DNA binding pocket, and consequently the resulting catalytic centers are not able to provide suitable interactions with prochiral substrates to promote efficient enantioselectivity. Therefore, to develop a suitable cofactor with the best fit to the binding pocket provided by G-quadruplex DNA is a key issue in constructing efficient artificial G-quadruplex metalloenzymes.

Through the lens of molecular biology, G-quadruplex DNAs are attractive targets for the development of anticancer drugs. ${ }^{38,39}$ Small molecules capable of inducing and stabilizing G-quadruplex DNA structure in human telomeres and oncogene-promoter regions have shown therapeutic intervention in cancer. $^{\mathbf{4 0 - 4 3}}$ It is reported that a series of terpyridine-metal complexes shows good affinity and high selectivity for human telomeric G-quadruplex DNA.4,45 Inspired by this specific recognition, in this work we have employed terpyridine- $\mathrm{Cu}$ (II) complexes $(\mathrm{CuL} n)$ as cofactors to construct human telomeric Gquadruplex DNA metalloenzymes. Our study shows that the resulting human telomeric G-quadruplex DNA-CuL1 can afford excellent catalytic function in a Diels-Alder reaction with both high enantioselectivity over 99\% enantiomeric excess (ee) and 
about 73-fold rate increase compared to $\mathrm{CuL} 1$ alone. To the best of our knowledge, this is the most efficient G-quadruplex DNA metalloenzyme for Diels-Alder reaction reported so far. Circular dichroism (CD) spectroscopic analysis, UV melting experiment and isothermal titration calorimetry (ITC) further indicate that the terpyridine- $\mathrm{Cu}$ (II) cofactor not only functions as a catalytic center but also plays an important role in inducing and stabilizing human telemetric G-quadruplex DNA with a catalytically active three-dimensional structure. Based on this proof-ofconcept experiment, it is envisioned that a much broader range of G-quadruplex metalloenzymes could be found by exploring the G-quadruplex-targeting ligand pool.

\section{Results}

\section{Terpyridine-Cu(II) complex targeting G-quadruplex DNA to produce artificial metalloenzyme}

Inspired by the G-quadruplex DNA targeting nature of terpyridine-metal complexes, we synthesized the terpyridine- $\mathrm{Cu}(\mathrm{II})$ complex (CuL1) and employed CuL1 to directly interact with a human telomeric DNA sequence (HT21) (Fig. 1a). CD spectroscopic analysis show that, upon interaction of CuL1 with HT21, an obvious spectral change in the region of $220-310 \mathrm{~nm}$ is observed, accompanied by a new CD band ranging from 310$370 \mathrm{~nm}$ (Fig. 1b). The spectral region of $310-370 \mathrm{~nm}$ originates from the electric transition of the terpyridine-Cu(II) core. ${ }^{46}$ Therefore, the new $\mathrm{CD}$ band $(310-370 \mathrm{~nm})$ can be readily ascribed to the induced circular dichroism (ICD) signal of CuL1 imposed by the chiral surroundings of HT21, which is also direct evidence of the CuL1-HT21 association. The CD spectrum of $220-310 \mathrm{~nm}$ is usually indicative of the G-quadruplex DNA structure. ${ }^{29-31}$ However, it is complicated in this system by the overlapping absorption band of CuL1. To aid in understanding the CD results, UV melting experiments were performed (Fig. 1c). The melting temperature $\left(T_{\mathrm{m}}\right)$ of HT21 increases by approximately $13{ }^{\circ} \mathrm{C}$ upon interaction with CuL1, which clearly indicates that the conformation of HT21 is significantly stabilized by the HT21-CuL1 complex formation. In this respect, the $\mathrm{CD}$ spectral change in the region of 220-310 $\mathrm{nm}$ contains much information on the structural transition of HT21. Moreover, the increased $T_{\mathrm{m}}$ clearly indicates that this structural transition occurs from a looser state to a more stable G-quadruplex DNA conformation. This deduction is further supported by the ITC experiment (Fig. 1d and e), which can determine the molecular nature of the binding interaction from a thermodynamic perspective. ${ }^{47}$ The binding isotherms reveal a complex binding process and can be best fit by a three-event model (Fig. 1e and Table S1†)..$^{48,49}$ The high-affinity binding site allows the interaction of one CuL1 molecule with HT21 by an affinity constant of approximately $10^{8} \mathrm{M}^{-1}$. Thermodynamic parameters further show that this strong association process is driven by a highly favorable enthalpy and a less unfavorable entropic contribution. The favorable enthalpy can be linked to either Hoogsteen hydrogen bond formation or association between CuL1 and HT21, which contributes to the structural regulation of HT21 from a looser state to a more stable Gquadruplex DNA conformation, whereas the unfavorable entropy change is mainly ascribed to decreased freedom from both the compact G-quadruplex DNA structure and the bound state of CuL1..$^{50}$

Upon confirming that CuL1 can directly induce and stabilize the HT21 G-quadruplex structure to form a stable HT21-CuL1 complex, we next selected the Diels-Alder reaction between azachalcone (1a) and cyclopentadiene (2) as a model to test the catalytic performance of HT21-CuL1. As shown in Table 1, HT21-CuL1 exhibits much higher catalytic performance than CuL1 alone (entry $2 v s$. entry 1), and catalyzes the reaction with $92 \%$ conversion (turnover number $(\mathrm{TON})=9.2$ ), high diastereoselectivity of product $3 \mathrm{a}$ (endo/exo of $97: 3$ ) and $90 \%$ ee of the major endo isomer in $24 \mathrm{~h}$ (entry 2). Although these catalytic data were modest compared with the results with a dsDNAbased metalloenzyme, ${ }^{15}$ this result gives the best enantiomeric outcome concerning G-quadruplex DNA-based catalysis. This finding thus proves that CuL1 can act as an effective cofactor for the construction of a human telomeric G-quadruplex DNA metalloenzyme. More interestingly, combining the structural analysis and catalytic data, it is obvious that the CuL1 cofactor not only serves as a catalytic center but also shows structural
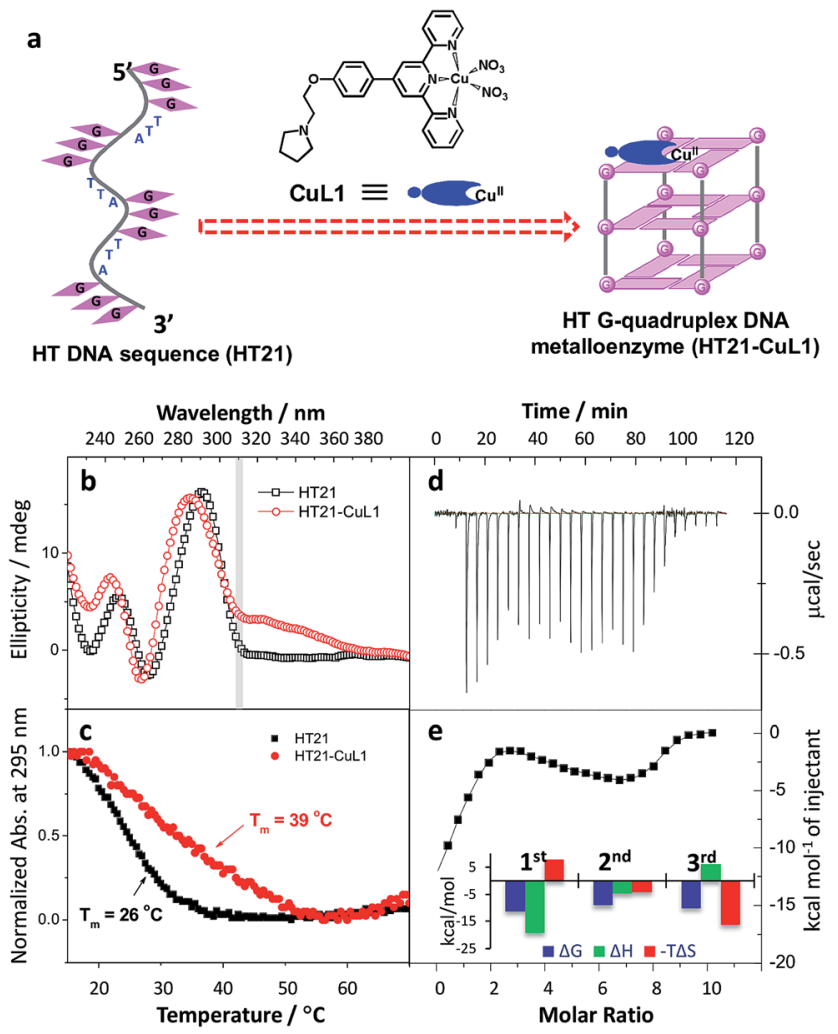

Fig. 1 Construction of human telomeric G-quadruplex DNA metalloenzyme. (a) Schematic diagram of molecular recognition between terpyridine-CU(॥) complex (CUL1) and human telomeric DNA sequence (HT21: 5' -(GGGTTA) $\left.{ }_{3} G G G-3^{\prime}\right)$. (b) CD spectra. (c) UV melting curves monitored by UV absorption at $295 \mathrm{~nm}$. (d and e) Isothermal titration calorimetry (ITC) experiment. Raw ITC data is shown in panel (d); plots of integrated calorimetric data after control subtraction (solid square), fitting curve (solid line) with a three-event binding model, and corresponding thermodynamic parameters are included in panel (e). 
Table 1 Diels-Alder reaction catalyzed by human telomeric G-quadruplex DNA metalloenzyme

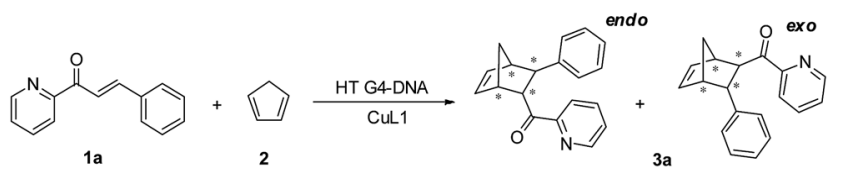

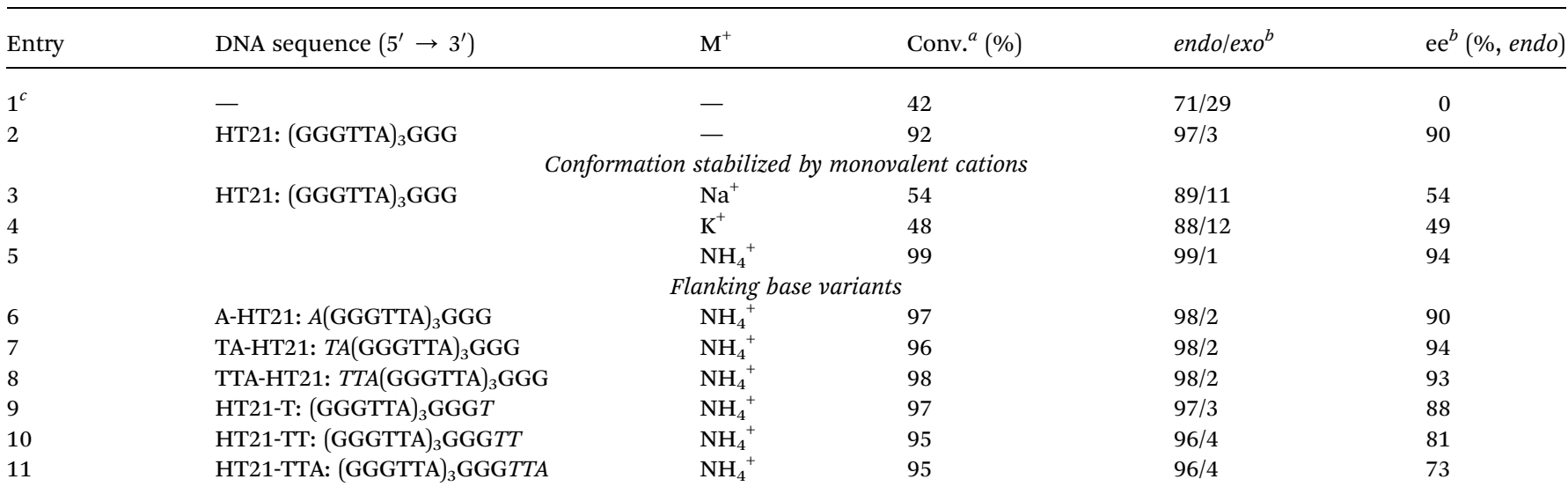

${ }^{a}$ Determined for the crude product by HPLC analysis on a chiral stationary phase (ESI note 5), reproducible within $\pm 2 \%{ }^{b}$ Determined by chiralphase HPLC. Reproducible within $\pm 2 \% .{ }^{c} \mathrm{Cu}(\mathbf{L 1})\left(\mathrm{NO}_{3}\right)_{2}$ alone as catalyst. Reaction conditions: $1 \mathrm{a}(1 \mathrm{mM}), 2(10 \mu \mathrm{L}, 260 \mathrm{mM})$, human telomeric Gquadruplex DNA $(50 \mu \mathrm{M}), \mathrm{Cu}(\mathbf{L 1})\left(\mathrm{NO}_{3}\right)_{2}(100 \mu \mathrm{M}), \mathrm{NaCl}(50 \mathrm{mM})$ or $\mathrm{KCl}(150 \mathrm{mM})$ or $\mathrm{NH}_{4} \mathrm{Cl}(30 \mathrm{mM}), \mathrm{MOPS}$ buffer $(0.5 \mathrm{~mL}, 20 \mathrm{mM}, \mathrm{pH} 6.5), 4{ }^{\circ} \mathrm{C}, 24$ h.

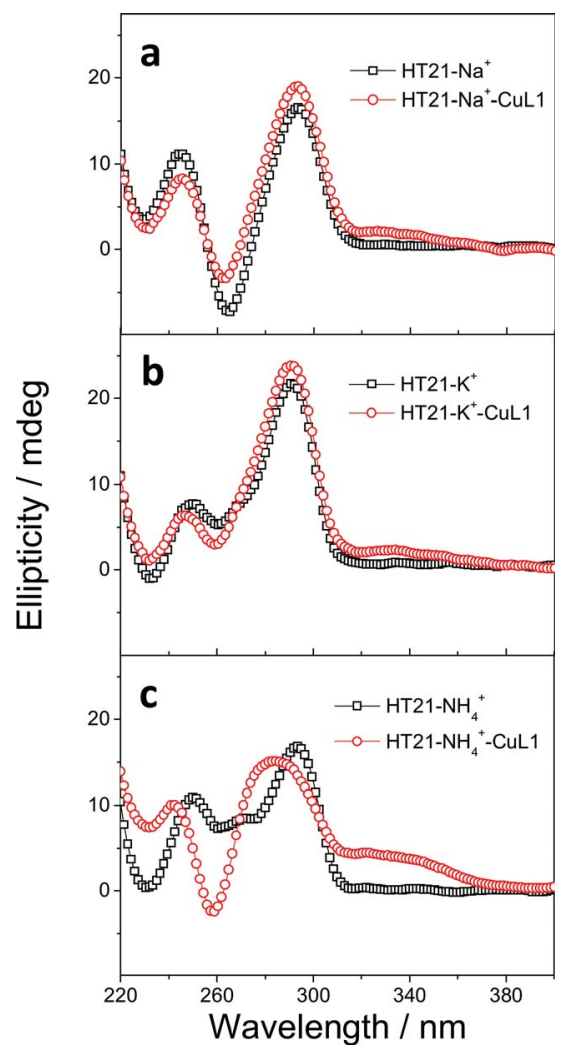

Fig. 2 CD spectra of HT21 in the presence of different monovalent cations and their corresponding metalloenzyme. (a) $50 \mathrm{mM} \mathrm{NaCl}$; (b) $150 \mathrm{mM} \mathrm{KCl}$; (c) $30 \mathrm{mM} \mathrm{NH}_{4} \mathrm{Cl}$ (DNA strand concentration, $5 \mu \mathrm{M}$; CuL1, $10 \mu \mathrm{M}$; MOPS buffer, 20 mM, pH 6.5). a
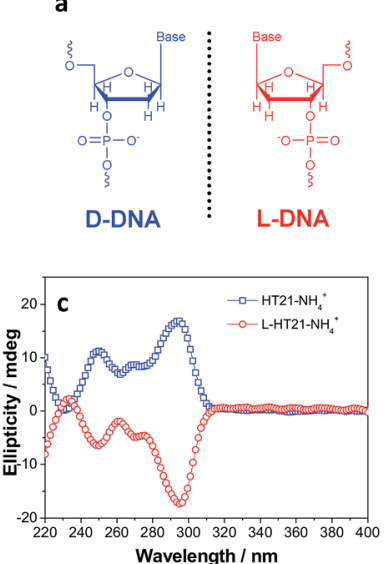

b

\begin{tabular}{lllll}
2 & $\mathrm{~L}-\mathrm{HT} 21$ & 99 & $98 / 2$ & -92 \\
\hline
\end{tabular}

Fig. 3 Inversion of global chirality of G-quadruplex DNA metalloenzyme. (a) Natural D-DNA building block for HT21 and its enantiomer for L-HT21. (b) The Diels-Alder reaction (1a and 2) catalyzed by HT21 and L-HT21 G-quadruplex DNA metalloenzymes. (c) CD spectra of HT21 and L-HT21 in $\mathrm{NH}_{4}{ }^{+}$media $\left(30 \mathrm{mM} \mathrm{NH}_{4} \mathrm{Cl}\right.$ ). (d) CD spectra of HT21 G-quadruplex DNA metalloenzyme and L-HT21 G-quadruplex DNA metalloenzyme.

regulation of human telomeric G-quadruplex DNA to promote excellent catalysis.

\section{Structural optimization of G-quadruplex DNA in artificial metalloenzyme}

In both natural and artificial metalloenzymes, subtle modifications of the secondary coordination sphere of the metal center usually exert a substantial influence on the catalytic 
Table 2 The ligand effect of terpyridine-Cu(I) cofactor on the catalytic function of human telomeric G-quadruplex DNA metalloenzyme
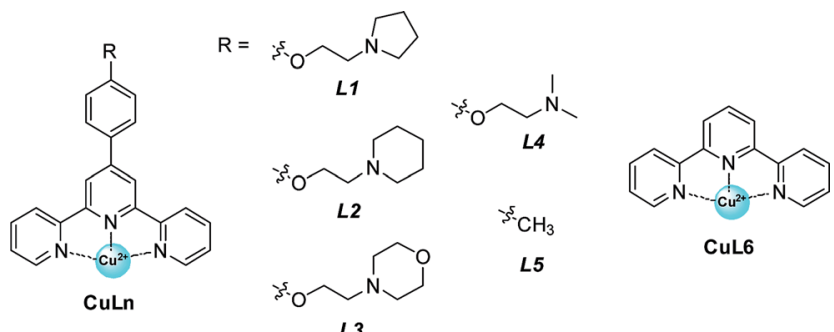

\begin{tabular}{lllll}
\hline Entry & Ligand & Conv. $^{a}(\%)$ & endo/exo $^{b}$ & ee $^{b}(\%$, endo $)$ \\
\hline 1 & L1 & 99 & $99 / 1$ & 94 \\
2 & L2 & 99 & $98 / 2$ & 93 \\
3 & L3 & 99 & $97 / 3$ & 92 \\
4 & L4 & 95 & $98 / 2$ & 93 \\
5 & L5 & 37 & $81 / 19$ & 18 \\
6 & L6 & 25 & $68 / 32$ & 6
\end{tabular}

${ }^{a}$ Determined for the crude product by HPLC analysis on a chiral stationary phase (ESI note 5), reproducible within $\pm 2 \%$. ${ }^{b}$ Determined by chiral-phase HPLC. Reproducible within $\pm 2 \%$. Reaction conditions: 1a $(1 \mathrm{mM}), 2(10 \mu \mathrm{L}, 260 \mathrm{mM})$, HT21 $(50 \mu \mathrm{M}), \mathrm{Cu}(\mathrm{L} n)\left(\mathrm{NO}_{3}\right)_{2}(100 \mu \mathrm{M})$, $\mathrm{NH}_{4} \mathrm{Cl}(30 \mathrm{mM})$, MOPS buffer (0.5 mL, $\left.20 \mathrm{mM}, \mathrm{pH} 6.5\right), 4{ }^{\circ} \mathrm{C}, 24 \mathrm{~h}$.

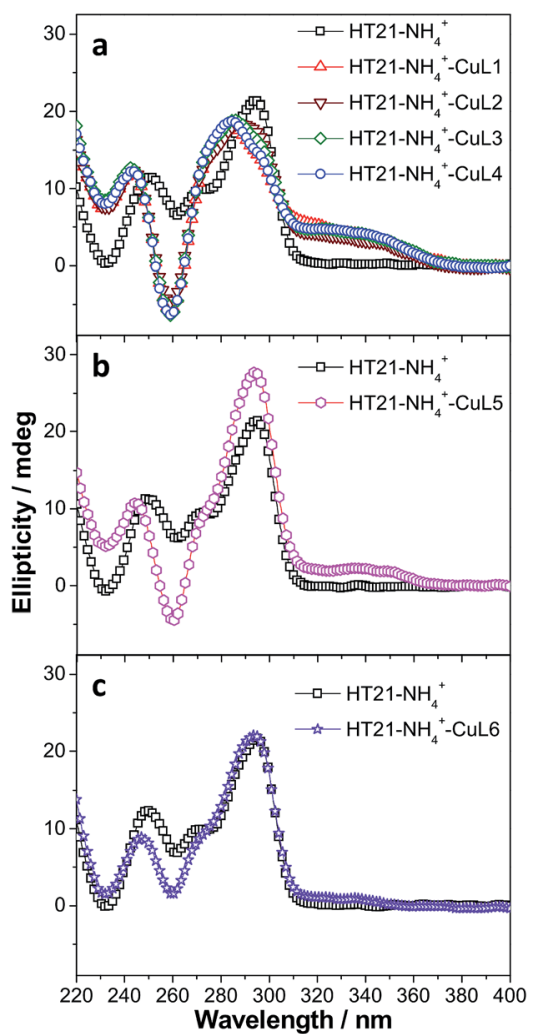

Fig. 4 CD spectra of human telomeric G-quadruplex DNA metalloenzymes with different terpyridine- $\mathrm{Cu}(॥)$ cofactors compared with HT21 itself in $\mathrm{NH}_{4}{ }^{+}$media. (a) CuL $n(n=1-4)$; (b) CuL5; (c) CuL6 (DNA strand concentration, $5 \mu \mathrm{M} ; \mathrm{NH}_{4} \mathrm{Cl}, 30 \mathrm{mM}$; CuLn, $10 \mu \mathrm{M}$; MOPS buffer, 20 mM, pH 6.5). function of the metalloenzyme. ${ }^{12,51}$ For the HT21-CuL1 metalloenzyme, this phenomenon provides an opportunity to improve the catalytic performance by varying the human telomeric G-quadruplex DNA structure. For this purpose, monovalent cations $\mathrm{M}^{+}\left(\mathrm{Na}^{+} / \mathrm{K}^{+} / \mathrm{NH}_{4}{ }^{+}\right)$were introduced to induce HT21 to form a G-quadruplex structure in advance, ${ }^{52}$ and then CuL1 was added to construct an artificial human telomeric Gquadruplex DNA metalloenzyme, represented by $\mathrm{HT} 21-\mathrm{M}^{+}-$ CuL1.

The CD spectra of HT21-Na ${ }^{+}$CuL1 (Fig. 2a) and HT21-K ${ }^{+}-$ CuL1 (Fig. 2b) indicate that CuL1 has less structural regulation for HT21 G-quadruplex DNA $(220-310 \mathrm{~nm})$, and the ICD signal for CuL1 $(310-370 \mathrm{~nm})$ is also obscure. However, for HT21- $\mathrm{NH}_{4}{ }^{+}-$ CuL1, substantial structural change of HT21 G-quadruplex DNA $(220-310 \mathrm{~nm})$ and a clear ICD signal $(310-370 \mathrm{~nm})$ are observed (Fig. 2c). In addition, HT21-M ${ }^{+}-\mathrm{CuL} 1$ shows distinct catalytic behaviors for the Diels-Alder reaction compared with HT21CuL1 (Table 1, entries 3-5 vs. entry 2). HT21-Na ${ }^{+}-\mathrm{CuL} 1$ shows an obvious decrease in both catalytic activity (conv. $=54 \%, \mathrm{TON}=$ 5.4 ) and enantioselectivity (54\% ee) (Table 1 , entry 3 ). A similar case holds for HT21- $\mathrm{K}^{+}-\mathrm{CuL1}$, with $48 \%$ conversion $(\mathrm{TON}=4.8$ ) and $49 \%$ ee (Table 1 , entry 4). Surprisingly, when $\mathrm{NH}_{4}{ }^{+}$was selected to stabilize HT21 G-quadruplex DNA, the HT21- $\mathrm{NH}_{4}{ }^{+}-$ CuL1 metalloenzyme demonstrated a substantial increase in catalytic activity compared with HT21-CuL1, showing 99\% conversion (TON $=9.9)$ and excellent diastereoselectivity (endo/ exo of 99:1), and the enantioselectivity for the major endo product 3a increased to $94 \%$ ee (Table 1, entry 5). For a comparison of intrinsic catalytic activity, we performed an enzymatic dynamics study. The Michaelis-Menten kinetics showed that the HT21- $\mathrm{NH}_{4}{ }^{+}-\mathrm{CuL} 1$ metalloenzyme reaches a catalytic efficiency $\left(k_{\text {cat }} / K_{\mathrm{M}}\right)$ of $36 \pm 4 \mathrm{M}^{-1} \mathrm{~s}^{-1}\left(k_{\text {cat }}=0.0015 \pm 0.0001 \mathrm{~s}^{-1}\right.$, $\left.K_{\mathrm{M}}=41 \pm 3 \mu \mathrm{M}\right)$, which is approximately 73-fold more active than CuL1 $\left(0.49 \pm 0.06 \mathrm{M}^{-1} \mathrm{~s}^{-1}\right)$ (Fig. S1 $\dagger$ ). The rate acceleration in this system is comparable to dsDNA-based catalysis. ${ }^{53}$ At the same time, $\mathrm{HT} 21-\mathrm{NH}_{4}{ }^{+}$-CuL1 metalloenzyme shows 10-fold rate increase compared to HT21-CuL1 (Fig. S1†). Based on the above results, it is concluded that $\mathrm{NH}_{4}{ }^{+}$ion can function as an efficient chaperone for the HT21 G-quadruplex DNA metalloenzyme to create a favorable modification of HT21 G-quadruplex DNA structure, which can help the CuL1 cofactor to fit well with the binding pocket within HT21 G-quadruplex DNA and consequently promote the Diels-Alder reaction.

Under optimized experimental conditions in $\mathrm{NH}_{4}{ }^{+}$media, we further modified the HT21 G-quadruplex structure by introducing 1-3 flanking bases at the $5^{\prime}$ or $3^{\prime}$ end. These two positions were selected because the binding of the terpyridine- $\mathrm{Cu}(\mathrm{II})$ complex with human telomeric G-quadruplex DNA suggests that the aromatic surface around the copper could interact with human telomeric G-quadruplex DNA by $\pi-\pi$ stacking on the external G-quartet. ${ }^{44}$ Therefore, the flanking bases at the $5^{\prime}$ or $3^{\prime}$ end are also expected to modify the microenvironment of the CuL1 cofactor in the HT21- $\mathrm{NH}_{4}{ }^{+}-\mathrm{CuL} 1$ metalloenzyme. For the Diels-Alder reaction between 1a and 2, these derivative human telomeric G-quadruplex DNA metalloenzymes present an interesting effect on the enantioselectivity (Table 1, entries 611). The sequences with flanking bases at the $5^{\prime}$-end have little 
Table 3 The binding thermodynamic parameters of different cofactors (CuLn) to human telomeric G-quadruplex DNA in 30 mM NH${ }_{4} \mathrm{Cl}$ at $298 \mathrm{~K}$

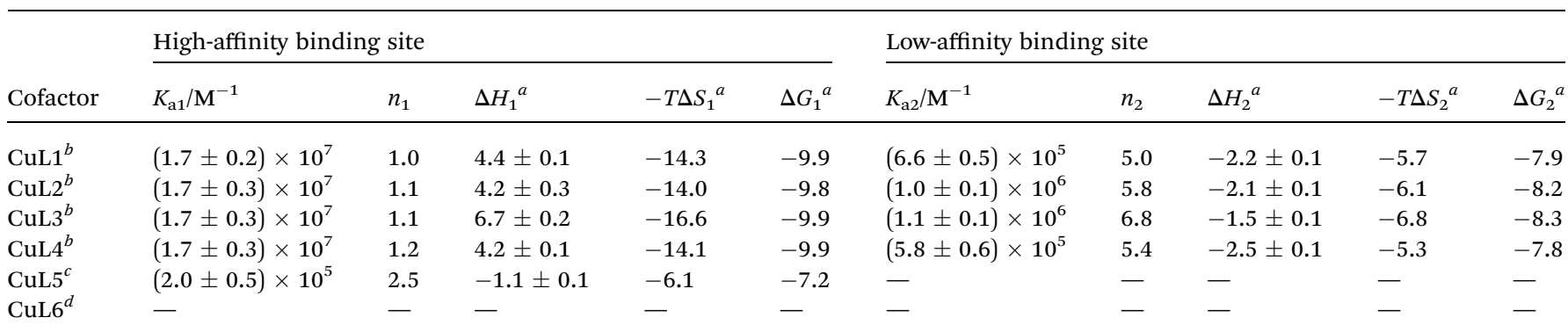

${ }^{a}$ Units are kcal mol ${ }^{-1} .{ }^{b}$ The data were obtained by the two-event binding model. ${ }^{c}$ The data were obtained by the one-event binding model. ${ }^{d}$ The affinity between the reactants is too low, neither the affinity nor the enthalpy of binding can be reliably determined.

effect on enantioselectivity (90-94\% ee) compared with HT21$\mathrm{NH}_{4}{ }^{+}$-CuL1 (Table 1, entries 6-8 vs. entry 5). In contrast, a negative effect on enantioselectivity can be observed when the flanking bases are at the $3^{\prime}$-end (Table 1 , entries 9-11 vs. entry 5). These data clearly indicate that the CuL1 cofactor is more sensitive to the $3^{\prime}$-end of HT21 G-quadruplex DNA, and a crowded microenvironment at the $3^{\prime}$-end is not favorable for high enantioselectivity.

The above data strongly suggest that the conformation of HT21 G-quadruplex DNA plays a dominant role in the enantioselective control. Therefore, based on the high level of enantioselectivity afforded by $\mathrm{HT} 21-\mathrm{NH}_{4}{ }^{+}-\mathrm{CuL} 1$, we further considered whether we could selectively access either enantiomer in the Diels-Alder reaction by tuning the HT21 Gquadruplex DNA conformation. To this end, mutation was performed by replacing the naturally occurring D-DNA with LDNA (Fig. 3a). CD spectra show that L-HT21 forms a G-quadruplex structure that is a mirror image of natural HT21 (Fig. 3c).
More importantly, upon assembly with CuL1, the resulting LHT21- $\mathrm{NH}_{4}{ }^{+}-\mathrm{CuL} 1$ metalloenzyme also presents the mirror image structure of natural HT21- $\mathrm{NH}_{4}{ }^{+}$-CuL1 (Fig. 3d). For the Diels-Alder reaction of $\mathbf{1 a}$ and $2, \mathrm{~L}-\mathrm{HT} 21-\mathrm{NH}_{4}{ }^{+}$-CuL1 can successfully switch the absolute configuration of the major product 3a from $94 \%$ ee to $-92 \%$ ee (Fig. $3 b$ ).

\section{Structural optimization of cofactor structure in artificial metalloenzyme}

Having validated the optimization of the second coordination sphere around $\mathrm{Cu}$ (II) by tuning the G-quadruplex structures, we further optimized the CuL $n$ cofactor by tuning the terpyridine ligand, namely the first coordination sphere around $\mathrm{Cu}^{\mathrm{II}}$ (Table 2). It is found that high catalytic activity and high enantioselectivity are not specific to CuL1 as a cofactor but are also obtained for other terpyridine-Cu(II) complexes possessing aminoethoxy side chains $\mathrm{R}(\mathrm{CuL} n, n=2-4)$ (Table 2, entries 1-

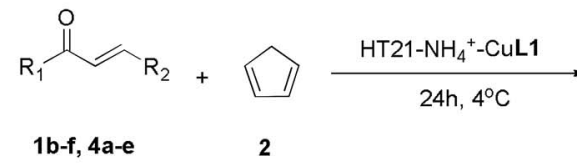<smiles>[R9]C(=O)C1C2CCC(C2)C1[R]</smiles>

endo<smiles>[R]C(=O)[C@H]1C2C=C[C@@H](C2)[C@H]1[R2]</smiles>

3b-f, 5a-e
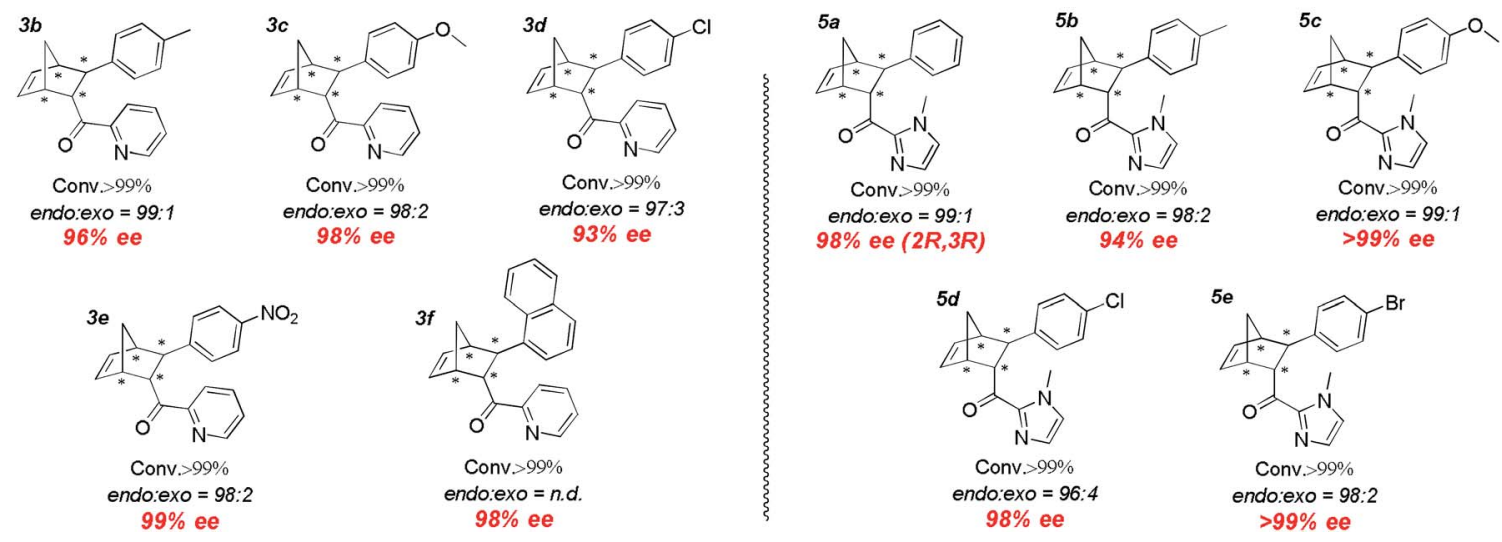

Fig. 5 Substrate scope for human telomeric G-quadruplex DNA metalloenzyme. Reaction conditions: 1 or 4 (1 mM), 2 (10 $\mu$ L, $260 \mathrm{mM}$ ), HT21 $(50 \mu \mathrm{M}), \mathrm{CuL1}(100 \mu \mathrm{M}), \mathrm{NH}_{4} \mathrm{Cl}(30 \mathrm{mM}), \mathrm{MOPS}$ buffer $(20 \mathrm{mM}, \mathrm{pH} 6.5), 4^{\circ} \mathrm{C}, 24 \mathrm{~h}$. All data are averaged over two experiments and are reproducible within $\pm 2 \%$. Conversion was measured by ${ }^{1} \mathrm{H}$ NMR analysis of the crude product. The endo/exo ratios and ee (for the endo isomer) were determined by chiral-phase HPLC. The absolute configuration of 5 a was obtained by literature comparison. ${ }^{16}$ 
4). In contrast, when the side chain (R) was changed from an aminoethoxy to a methyl group (CuL5), the HT21- $\mathrm{NH}_{4}{ }^{+}-\mathrm{CuL} 5$ metalloenzyme showed a substantial decline in both catalytic activity (conv. $=37 \%$, TON $=3.7)$ and enantioselectivity $(18 \%$ ee) (Table 2, entry 5). With further removal of the aromatic ring (CuL6), the HT21- $\mathrm{NH}_{4}{ }^{+}$-CuL6 metalloenzyme led to only $25 \%$ conversion $(\mathrm{TON}=2.5)$ and a complete inhibition of enantioselectivity (Table 2, entry 6). These catalytic data show that both the aminoethoxy side chain and the aromatic ring are key components for the terpyridine-Cu(II) cofactor to construct an efficient human telomeric G-quadruplex DNA metalloenzyme.

To clarify the underlying reason, we further focused on structural understanding of the HT21- $\mathrm{NH}_{4}{ }^{+}-\mathrm{CuLn}$ metalloenzymes. We first used CD spectroscopy to detect the interaction of $\mathrm{HT} 21-\mathrm{NH}_{4}{ }^{+}$with terpyridine-Cu(II) complexes possessing different side chains (Fig. 4). In comparison with HT21- $\mathrm{NH}_{4}{ }^{+}$itself, all test terpyridine-Cu(II) cofactors demonstrate structural regulation on the HT21 G-quadruplex DNA structure (220-310 $\mathrm{nm}$ ), but the degree of structural change is strongly dependent upon the type of side chain (R). At the same time, the ICD signals of the terpyridine-Cu(II) cofactor (310-370 nm) imposed by HT21 G-quadruplex DNA also vary with different side chains. In detail, $\mathrm{HT} 21-\mathrm{NH}_{4}{ }^{+}-\mathrm{CuLn}(n=1-4)$ metalloenzymes with terpyridine-Cu(II) cofactors possessing aminoethoxy side chains show similar CD spectral features, with clear structural regulation of the HT21 G-quadruplex DNA (220-310 nm) accompanied by the appearance of a strong ICD signal of the CuLn cofactors (Fig. 4a). Upon changing the cofactor to CuL5 (Fig. 4b), the structural transition of HT21 Gquadruplex DNA is also observed but shows a distinct CD feature from the HT21- $\mathrm{NH}_{4}{ }^{+}-\mathrm{CuL} n(n=1-4)$ metalloenzyme. Moreover, HT21- $\mathrm{NH}_{4}{ }^{+}-\mathrm{CuL} 5$ exhibits a smaller magnitude of ICD signal compared with $\mathrm{HT} 21-\mathrm{NH}_{4}{ }^{+}-\mathrm{CuL} n(n=1-4)$. Upon changing to CuL6, the structural transition of HT21 becomes less notable, and the ICD signal is also obscured (Fig. 4c). The ICD signal in the wavelength region $310-370 \mathrm{~nm}$ originates from the electric transition of the terpyridine- $\mathrm{Cu}$ (II) core, which is common to all six CuLn cofactors. Thus, the distinct amplitude of the ICD signal in $\mathrm{HT} 21-\mathrm{NH}_{4}{ }^{+}-\mathrm{CuL} n$ indicates a different molecular orientation of the terpyridine-Cu(II) chromophore relative to the surrounding nucleobases, ${ }^{54}$ which gives direct evidence of different recognition between CuLn and HT21$\mathrm{NH}_{4}{ }^{+}$G-quadruplex DNA. More interestingly, a positive correlation between catalytic performance and amplitude of ICD signal indicates that the catalytic function of $\mathrm{HT} 21-\mathrm{NH}_{4}{ }^{+}-\mathrm{CuLn}$ metalloenzyme is strongly dependent on the molecular recognition between CuLn and HT21 G-quadruplex DNA.

This conclusion based on CD data is further supported by ITC data (Table 3, Fig. S2 and S3 $\dagger$ ). For terpyridine-Cu(II) complexes possessing aminoethoxy side chains ( $\mathrm{CuL} n, n=1-4)$, all binding isotherms are similar and reveal obvious two-event binding process. The high-affinity binding process, with a binding constant $\left(K_{\mathrm{a} 1}\right)$ of $1.7 \times 10^{7} \mathrm{M}^{-1}$, is the result of a highly favorable entropy change and a smaller unfavorable enthalpy change. The low-affinity binding process displays a binding constant $\left(K_{\mathrm{a} 2}\right)$ of $5.8 \times 10^{5}-1.1 \times 10^{6} \mathrm{M}^{-1}$, which is $16-30$ times lower than the $K_{\mathrm{a} 1}$. In contrast to the high-affinity binding process, this low-affinity binding is favored by both entropy and enthalpy changes. The titration of CuL5 into $\mathrm{HT} 21-\mathrm{NH}_{4}{ }^{+}$ displays a relatively simple binding isotherm. A binding constant $\left(K_{\mathrm{a}}\right)$ of $2.0 \times 10^{5} \mathrm{M}^{-1}$ is estimated by fitting a single binding event model, which is of the same order of magnitude as the low-affinity binding of $\mathrm{CuLn}(n=1-4)$ to $\mathrm{HT} 21-\mathrm{NH}_{4}{ }^{+} \mathrm{G}$ quadruplex DNA. Furthermore, the molecular recognition process between CuL5 and $\mathrm{HT} 21-\mathrm{NH}_{4}{ }^{+}$G-quadruplex DNA also shows a similar thermodynamic signature to the low-affinity binding of $\mathrm{CuLn}(n=1-4)$ to $\mathrm{HT} 21-\mathrm{NH}_{4}{ }^{+}$G-quadruplex DNA (Fig. S3†). In contrast, the binding isotherm of CuL6 to HT21$\mathrm{NH}_{4}{ }^{+}$is essentially the same as the background calorimetric titration of MOPS buffer to HT21- $\mathrm{NH}_{4}{ }^{+}$, suggesting that weak binding between CuL6 and HT21- $\mathrm{NH}_{4}{ }^{+}$occurs, and neither the binding constant nor the thermodynamic parameters can be reliably determined. Thus, based on the different energetic characteristics, the ITC results clearly show three types of molecular recognition processes, and correspondingly, these three distinct interaction processes give the binding affinity order of CuLn $(n=1-4)>\mathrm{CuL} 5>\mathrm{CuL} 6$ to $\mathrm{HT} 21-\mathrm{NH}_{4}{ }^{+} \mathrm{G}^{-}$ quadruplex DNA. This sequence is consistent with not only the amplitude of the ICD signal in the CD experiment discussed above but also the $\Delta T_{\mathrm{m}}$ values in UV melting experiments, where CuLn $(n=1-4)$ increases the melting temperature of HT21- $\mathrm{NH}_{4}{ }^{+}$most significantly $\left(\Delta T_{\mathrm{m}} \approx 20^{\circ} \mathrm{C}\right)$, followed by CuL5 $\left(\Delta T_{\mathrm{m}} \approx 10{ }^{\circ} \mathrm{C}\right)$ and CuL6 $\left(\Delta T_{\mathrm{m}} \approx 5{ }^{\circ} \mathrm{C}\right)$ (Fig. S4 $\dagger$ ).

In connection with the catalytic data and the above characterizations (CD, UV melting and ITC), we thus concluded that the molecular recognition between HT21 G-quadruplex DNA and terpyridine- $\mathrm{Cu}$ (II) plays an essential role in the catalytic function of the $\mathrm{HT} 21-\mathrm{NH}_{4}{ }^{+}-\mathrm{CuLn}$ metalloenzyme. In fact, the high affinity of CuLn $(n=1-4)$ for HT21 G-quadruplex DNA can be easily understood as the interplay of two effects: (1) the $\pi-\pi$ stacking interactions between the terpyridine and the Gquartet; (2) the electrostatic interaction between the positive charge of the aminoalkyl group and the negative charge of the phosphate backbones. ${ }^{44,55}$

\section{Substrate scope}

With the excellent HT21- $\mathrm{NH}_{4}{ }^{+}-\mathrm{CuL} 1$ metalloenzyme in hand, we further tested the substrate specificity (Fig. 5). The HT21$\mathrm{NH}_{4}{ }^{+}$-CuL1 metalloenzyme was found to be an active catalyst for all the tested aza-chalcone substrates (1b-f). In general, the introduction of a bulkier $\mathrm{R}_{2}$ group has a positive influence on the enantioselectivity. In particular, $\mathrm{R}_{2}$ with a nitro group afforded up to $99 \%$ ee (3e). Furthermore, high activity and enantioselectivity are also observed for the other type of dienophiles possessing acylimidazolyl groups (4a-e). Nearly pure isomers (>99\% ee) are obtained for $4-\mathrm{MeO}$ and $4-\mathrm{Br}$ (5c and $5 \mathbf{e})$.

\section{Discussion}

Small molecule targeting of G-quadruplex DNA represents an attractive approach to anticancer drug design. ${ }^{\mathbf{4 0 - 4 3}}$ This recognition process is analogous to the assembly of an artificial enzyme between a catalytic cofactor and a biomolecular 
scaffold. ${ }^{10-12}$ Following this idea, we have found an excellent Gquadruplex metalloenzyme through molecular recognition between terpyridine-Cu(II) and human telomeric G-quadruplex DNA, although the precise nature of the interaction is not well known. This modular assembly method allows rationally tunable enantioselectivity of the Diels-Alder reaction. The Gquadruplex DNA scaffold can be modulated by the addition of cation, modification of flanking bases at the $3^{\prime}$-end, and even inversion of global chirality by replacing natural D-DNA with unnatural L-DNA. Modification of the substituent in the terpyridine ligand can also change the binding affinity between Gquadruplex DNA and the terpyridine-Cu(II) cofactor, which alters the microenvironment of the active site. Based on this proof-of-concept experiment, we expect this approach to provide a general method to find a broad variety of G-quadruplex metalloenzymes by screening G-quadruplex-targeting ligand pools.

\section{Conclusions}

In conclusion, we have designed a G-quadruplex metalloenzyme that can afford both high catalytic activity and high enantioselectivity (up to 99\% ee) for the Diels-Alder reaction. The success of this artificial metalloenzyme can be ascribed to the G-quadruplex DNA-targeting nature of terpyridine-Cu(II). The terpyridine-Cu(II) cofactor is found to play dual roles as both an active site for chemical catalysis and a structural regulator for the folding of the catalytic DNA structure. A positive correlation between the affinity of terpyridine-Cu(II) for HT21 and the enantioselectivity of the Diels-Alder reaction is observed, which further confirms the importance of molecular recognition in constructing artificial G-quadruplex DNA metalloenzymes. Our work paves a new way to design G-quadruplex-based DNAzymes by learning from G-quadruplex-targeting drug design.

\section{Acknowledgements}

We thank Prof. Yan Liu, Dr Jun Zhou, Dr Shengmei Lu and Dr Jun Li for their helpful discussions. This work is financially supported by National Natural Science Foundation of China (grant numbers 31000392, 21173213).

\section{Notes and references}

1 T. Bugg, Introduction to enzyme and coenzyme chemistry, Blackwell Pub., Oxford, UK; Malden, MA, USA, 3rd edn, 2012.

2 W. D. Fessner and T. Anthonsen, Modern biocatalysis : stereoselective and environmentally friendly reactions, WileyVCH, Weinheim, 2009.

3 D. E. Metzler and C. M. Metzler, in Biochemistry : the chemical reactions of living cells, Harcourt/Academic Press, San Diego, CA, 2nd edn, 2001, vol. 1, ch. 16, p. 837.

4 K. L. Harris, S. Lim and S. J. Franklin, Inorg. Chem., 2006, 45, 10002.

5 Y. Lu, N. Yeung, N. Sieracki and N. M. Marshall, Nature, 2009, 460, 855.
6 M. Dürrenberger and T. R. Ward, Curr. Opin. Chem. Biol., 2014, 19, 99.

7 I. D. Petrik, J. Liu and Y. Lu, Curr. Opin. Chem. Biol., 2014, 19, 67.

8 F. Yu, V. M. Cangelosi, M. L. Zastrow, M. Tegoni, J. S. Plegaria, A. G. Tebo, C. S. Mocny, L. Ruckthong, H. Qayyum and V. L. Pecoraro, Chem. Rev., 2014, 114, 3495.

9 M. T. Reetz, Angew. Chem., Int. Ed., 2011, 50, 138.

10 R. Krämer, Angew. Chem., Int. Ed., 2006, 45, 858.

11 T. R. Ward, Acc. Chem. Res., 2011, 44, 47.

12 J. Bos and G. Roelfes, Curr. Opin. Chem. Biol., 2014, 19, 135. 13 A. Jäschke, in Molecular encapsulation: organic reactions in constrained systems, John Wiley \& Sons, Ltd, 2010, ch. 14, p. 377.

14 S. Park and H. Sugiyama, Angew. Chem., Int. Ed., 2010, 49, 3870.

15 G. Roelfes, A. J. Boersma and B. L. Feringa, Chem. Commun., 2006, 635.

16 A. J. Boersma, B. L. Feringa and G. Roelfes, Org. Lett., 2007, 9, 3647.

17 D. Coquière, B. L. Feringa and G. Roelfes, Angew. Chem., Int. Ed., 2007, 46, 9308.

18 E. W. Dijk, B. L. Feringa and G. Roelfes, Tetrahedron: Asymmetry, 2008, 19, 2374.

19 A. J. Boersma, B. L. Feringa and G. Roelfes, Angew. Chem., Int. Ed., 2009, 48, 3346.

20 N. Shibata, H. Yasui, S. Nakamura and T. Toru, Synlett, 2007, 1153.

21 Y. H. Li, C. H. Wang, G. Q. Jia, S. M. Lu and C. Li, Tetrahedron, 2013, 69, 6585.

22 J. Wang, E. Benedetti, L. Bethge, S. Vonhoff, S. Klussmann, J.-J. Vasseur, J. Cossy, M. Smietana and S. Arseniyadis, Angew. Chem., Int. Ed., 2013, 52, 11546.

23 L. Gjonaj and G. Roelfes, ChemCatChem, 2013, 5, 1718.

24 H. Zhao and K. Shen, RSC Adv., 2014, 4, 54051.

25 E. Benedetti, N. Duchemin, L. Bethge, S. Vonhoff, S. Klussmann, J.-J. Vasseur, J. Cossy, M. Smietana and S. Arseniyadis, Chem. Commun., 2015, 51, 6076.

26 A. Draksharapu, A. J. Boersma, M. Leising, A. Meetsma, W. R. Browne and G. Roelfes, Dalton Trans., 2015, 44, 3647.

27 S. Burge, G. N. Parkinson, P. Hazel, A. K. Todd and S. Neidle, Nucleic Acids Res., 2006, 34, 5402.

28 J. Dai, M. Carver and D. Yang, Biochimie, 2008, 90, 1172.

29 J. Kypr, I. Kejnovská, D. Renčiuk and M. Vorlíčková, Nucleic Acids Res., 2009, 37, 1713.

30 D. M. Gray, J. D. Wen, C. W. Gray, R. Repges, C. Repges, G. Raabe and J. Fleischhauer, Chirality, 2008, 20, 431.

31 S. Masiero, R. Trotta, S. Pieraccini, S. De Tito, R. Perone, A. Randazzo and G. P. Spada, Org. Biomol. Chem., 2010, 8, 2683.

32 S. Roe, D. J. Ritson, T. Garner, M. Searle and J. E. Moses, Chem. Commun., 2010, 46, 4309.

33 C. H. Wang, G. Q. Jia, J. Zhou, Y. H. Li, Y. Liu, S. M. Lu and C. Li, Angew. Chem., Int. Ed., 2012, 51, 9352.

34 C. H. Wang, Y. H. Li, G. Q. Jia, Y. Liu, S. M. Lu and C. Li, Chem. Commun., 2012, 48, 6232. 
35 C. H. Wang, G. Q. Jia, Y. H. Li, S. F. Zhang and C. Li, Chem. Commun., 2013, 49, 11161.

36 Y. H. Li, G. Q. Jia, C. H. Wang, M. P. Cheng and C. Li, ChemBioChem, 2015, 16, 618.

37 M. Wilking and U. Hennecke, Org. Biomol. Chem., 2013, 11, 6940.

38 H. Y. Han and L. H. Hurley, Trends Pharmacol. Sci., 2000, 21, 136.

39 S. Neidle, FEBS J., 2010, 277, 1118.

40 D. J. Patel, A. T. Phan and V. Kuryavyi, Nucleic Acids Res., 2007, 35, 7429.

41 A. Arola and R. Vilar, Curr. Top. Med. Chem., 2008, 8, 1405.

42 D. Z. Yang and K. Okamoto, Future Med. Chem., 2010, 2, 619. 43 N. W. Luedtke, Chimia, 2009, 63, 134.

44 H. Bertrand, D. Monchaud, A. De Cian, R. Guillot, J.-L. Mergny and M.-P. Teulade-Fichou, Org. Biomol. Chem., 2007, 5, 2555.

45 S. N. Georgiades, N. H. Abd Karim, K. Suntharalingam and R. Vilar, Angew. Chem., Int. Ed., 2010, 49, 4020.
46 I. Eryazici, C. N. Moorefield and G. R. Newkome, Chem. Rev., 2008, 108, 1834.

47 I. Haq, B. Z. Chowdhry and T. C. Jenkins, Methods Enzymol., 2001, 340, 109.

48 V. H. Le, R. Buscaglia, J. B. Chaires and E. A. Lewis, Anal. Biochem., 2013, 434, 233.

49 J. S. Hudson, L. Ding, V. Le, E. Lewis and D. Graves, Biochemistry, 2014, 53, 3347.

50 D. H. Williams, E. Stephens, D. P. O'Brien and M. Zhou, Angew. Chem., Int. Ed., 2004, 43, 6596.

51 A. J. Kirby, Angew.Chem., Int. Ed. Engl., 1996, 35, 706.

52 N. V. Hud and J. Plavec, in Quadruplex Nucleic Acids, ed. S. Neidle and S. Balasubramanian, RSC, Cambridge, 2006, p. 100.

53 A. J. Boersma, J. E. Klijn, B. L. Feringa and G. Roelfes, J. Am. Chem. Soc., 2008, 130, 11783.

54 M. Eriksson and B. Norden, Methods Enzymol., 2001, 340, 68. 55 C. Wei, L. Ren and N. Gao, Int. J. Biol. Macromol., 2013, 57, 1. 